\title{
CONCEPT OF MEDICAL PSYCHOPHYSIOLOGICAL EXAMINATION OF PERSONNEL OF NUCLEAR FACILITIES
}

Torubarov FS, Bushmanov AYu, Zvereva ZF $\bowtie$, Kretov AS, Lukyanova SN, Denisova EA

State Scientific Center of the Burnazyan Federal Medical and Biological Center, Moscow, Russia

Ensuring safety of the facilities employing radiation and nuclear hazardous technologies is a priority task for medical organizations serving these facilities. To perform safely at their jobs, it is important for the personnel of nuclear facilities (NF) to have their central nervous systems functioning flawlessly. Certain categories of nuclear industry workers are required to undergo compulsory annual medical examinations (ME) and psychophysiological examinations. This study aimed to develop a concept of psychophysiological examination of NF personnel allowing to assess the central nervous system's functional status. The study involved three groups of nuclear corporation employees (male) counting 720, 364 and 24 people aged from $46 \pm 5.3$ to $49 \pm 6.1$ years. The report describes the suggested concept of psychophysiological examination of the specified category of workers, discusses goals, objectives and the procedure of such an examination at all stages of compulsory ME, covers the developed hardware and software sets. The proposed methodological approach is evaluated through consideration of the results of psychophysiological examination of the specified category of workers.

Keywords: workers, nuclear facilities, psychophysiological examination, concept, functional state, central nervous system

Author contribution: FS Torubarov, ZF Zvereva - data processing and article authoring. All authors participated in the discussion of the results.

Compliance with ethical standards: the study was approved by the Ethics Committee of the State Scientific Center of the A.I. Burnazyan Federal Medical and Biological Center (minutes \#32s of October 31, 2018); all human research procedures conform to the requirements set by the institutional and/or national committee on research ethics and the 1964 Declaration of Helsinki and its subsequent amendments.

$\triangle$ Correspondence should be addressed: Zoya F. Zvereva

Pestelya, 9, ap. 146, Moscow, 127490; zvereva01@yandex.ru

Received: 19.02.2021 Accepted: 02.03.2021 Published online: 20.03.2021

DOI: $10.47183 /$ mes.2021.008

\section{КОНЦЕПЦИЯ ПСИХОФИЗИОЛОГИЧЕСКОГО ОБСЛЕДОВАНИЯ ПЕРСОНАЛА ОБЪЕКТОВ ИСПОЛЬЗОВАНИЯ АТОМНОЙ ЭНЕРГИИ В МЕДИЦИНСКИХ ОРГАНИЗАЦИЯХ}

\author{
Ф. С. Торубаров, А. Ю. Бушманов, З. Ф. Зверева $\bowtie$, А. С. Кретов, С. Н. Лукьянова, Е. А. Денисова \\ Государственный научный центр Федерального медико-биологического центра имени А.И. Бурназяна, Москва, Россия
}

\begin{abstract}
Обеспечение безопасности объектов, использующих радиационно и ядерно опасные технологии, является приоритетной задачей медицинских организаций, обслуживающих эти предприятия. Для безопасной реализации работниками объектов использования атомной энергии (ОИАЭ) профессиональной деятельности важно высокое функциональное состояние их центральной нервной системы. Отдельные категории сотрудников атомной отрасли обязаны проходить обязательные ежегодные медицинские осмотры (МО) и психосизиологические обследования. Целью исследования было разработать концепции психофизиологического осмотра персонала ОИАЭ для оценки функционального состояния центральной нервной системы. В исследовании участвовали три группы работников (мужчины) атомной корпорации численностью 720,364 и 24 человека в возрасте от $46 \pm$ 5,3 до $49 \pm$ 6,1 года. Предложена концепция психофизиологического обследования указанной категории работников, обсуждаются цели, задачи, порядок проведения психофизиологического обследования на всех этапах обязательных МО, разработаны аппаратно-программные комплексы. Для оценки предлагаемого методического подхода рассмотрены результаты психофизиологического обследования указанной категории работников.
\end{abstract}

Ключевые слова: работники, объекты использования атомной энергии, психосизиологическое обследование, концепция, функциональное состояние, центральная нервная система

Вклад авторов: Ф. С. Торубаров, З. Ф. Зверева - обработка данных и написание текста статьи. Все авторы участвовали в обсуждении результатов.

Соблюдение этических стандартов: исследование одобрено этическим комитетом ГНЦ ФМБЦ им. А. И. Бурназяна (протокол № 32с от 31 октября 2018 г.); все процедуры, выполненные в исследовании с участием людей, соответствуют требованиям институционального и/или национального комитета по исследовательской этике и Хельсинкской декларации 1964 г. и ее последующим изменениям.

$\triangle$ Для корреспонденции: Зоя Фёдоровна Зверева

ул. Пестеля, д. 9, кв. 146, г. Москва, 127490; zvereva01@yandex.ru

Статья получена: 19.02.2021 Статья принята к печати: 02.03.2021 Опубликована онлайн: 20.03.2021

DOI: $10.47183 /$ mes.2021.008

Ensuring safety of the facilities employing radiation and nuclear hazardous technologies is a priority task for the relevant services and medical organizations serving such facilities. Despite technological advancements and widespread automation, human factor still plays a significant role. To mitigate the possible adverse impact thereof, certain categories of specialists permitted to work in the field of atomic energy are required to undergo medical examinations (ME) and psychophysiological examinations (PPE) in medical organizations.

Currently, under normal operating conditions, the staff of nuclear facilities cannot be exposed to ionizing radiation in doses exceeding the established standards. Professionally, such specialists perform under the burden of high responsibility, significant mental stress, need to be able to quickly perceive information, process it and respond. To successfully discharge these duties and work in the conditions described, they need their central nervous system (CNS) to have a high functional state (FS).

According to the current concepts, FS of CNS determines the general functional state of the body [1]. Nervous system is considered to be the physiological basis of regulation mechanisms. From the psychophysiological viewpoint, FS of CNS is conditioned by the level of activation of and interaction between modulating - specific and nonspecific - structuralfunctional formations (SFF) of the brain [2, 3]. In case of nuclear facility employees, process safety and efficiency directly depends on the FS of their CNS. PPE allows assessing FS of CNS. 
The purpose of PPE is to identify persons with psychophysiological contraindications for employment at NF. The goals of PPE include assessment of the functional activity of SFF of CNS and conclusion about FS of the employee's CNS $[4,5]$.

As of 2019, there are 26 psychophysiological examination laboratories (PPEL) operating under medical organizations serving nuclear facilities in Russia. This fact necessitates development and implementation of common methodological approaches and methods, as well as a single PPE protocol applicable at all stages of medical monitoring of the personnel's condition $[4,5]$.

This study aimed to develop nuclear industry personnel PPE concepts and evaluate the suggested methodological approach.

\section{METHODS}

The study involved three groups of nuclear corporation employees that underwent PPE in 2015-2017 as part of routine medical checkups. The inclusion criteria required the participants to not have any contraindications for working at a nuclear facility.

Group 1: 720 employees of ten nuclear power plants (NPP), mean age $49 \pm 6.1$ years; inclusion criterion - underwent PPE as part of routine medical checkup.

Group 2: 364 NPP operators, mean age $46 \pm 5.3$ years; inclusion criterion - underwent PPE as part of pre-shift medical examination.

Group 3: 24 people, mean age $48 \pm 6.3$ years; inclusion criterion - underwent PPE as part of evaluation of the results of rehabilitation and health improvement courses $(\mathrm{RHIC})$ in a hospital.

PPE In the context of routine medical checkups of NPP employees, as well as those that underwent $\mathrm{RHIC}$, relied on the PFS-Kontrol hardware and software set (H\&S) [6]. The subject of evaluation were the results of application of the following tests/methods.

- psychodiagnostic techniques: MMPI methodology; Sixteen Personality Factor Questionnaire, 16PF; Raven's Matrices; subjective control level (SCL);

- psychophysiological techniques (visual-motor tests): simple visual-motor reaction test, SVMRT; complex visualmotor reaction test, CVMRT, reaction to moving object (RMO)

- physiological technique: heart rate variability (HRV).

Prognoz H\&S was used in the context of pre-shift examinations [7].

The statistical differences were assessed with the help of the $\chi^{2}$ test, the level of significance was set at $p<0.05$.

\section{RESULTS}

The search for a common approach to assessment of the FS of CNS based on the employee's PPE results yielded a psychophysiological examination concept (Fig. 1).

Three structural and functional formations in the brain were selected as those allowing assessment of FS of CNS relying on the PPE results. Psychodiagnostic techniques (MMPI, 16PF, Raven's Matrices, SCL) allowed identifying the "cortex" SFF, psychophysiological techniques (SVMRT, CVMRT, RMO) - the "cortical-subcortical interaction" SFF, physiological techniques (HRV) - the "cardiovascular system central regulation" SFF $[6,8,9]$.

The functional activity (FA) of the SFF could be high, medium and low, all within the limits of acceptable values. It could also go beyond those limits. The SFF FS indicators allowed making a final conclusion about FS of CNS.

All stages of medical monitoring routines should include PPE, but the purpose attached to each stage is unique. Figure 2 shows the medical monitoring diagram.

During the preliminary $\mathrm{ME}$, the main task is to identify psychophysiological contraindications for work. PPE results are included in the preliminary ME's general report; if there are psychophysiological contraindications, the candidate is not hired. It should be noted that it is advisable to accumulate indicators registered with each PPE test and the general conclusion drawn thereof in a special database.

For persons hired, further medical monitoring routines are shaped by the results of preliminary ME and PPE.

In the context of regular ME, PPE solves two tasks:

1) identify persons with unacceptable values of indicators of functional activity of CNS SFF, who are suspended from work for an in-depth medical examination to make a decision on the possibility of continuing the employment;

2) identify persons with low but permissible values of indicators of functional activity of CNS SFF, who are added to the risk group and sent to $\mathrm{RHIC}$.

As a rule, regular medical examinations take place once a year, and on the daily basis, the employee's FS of CNS is controlled with pre-shift ME and PPE.

Pre-shift ME allow identifying persons in a disabled state, including those intoxicated with alcoholic, narcotic or other toxic substances or exhibiting residual effects thereof. Pre-shift psychophysiological control uncovers functional disorders of CNS that may significantly hamper professional reliability of an employee.

Thus, the goal of pre-shift PPE is to identify workers whose FS of CNS prevents them from working the given shift. The time allocated for PPE as part of the pre-shift control routine is limited. Therefore, the important technical requirements for PPE of this stage are efficiency, personalized character, exhaustive descriptiveness.

At the RHIC stage, PPE aims to objectively assess the FS of CNS before and after the procedures.

It is mandatory for medical organizations conducting PPE to develop and deploy a special database that summarizes the results of examinations at all stages.

A PPE database enables timely medical, organizational and managerial decisions made with the aim to improve radiation and nuclear safety of the nuclear industry plants and facilities.

From our point of view, in the context of laboratory ME, PPE should not only apply a set of methods and techniques common to all sych examinations, but also employ H\&S sets that meet a unified list of requirements. Such an approach would allow comparing PPE results obtained at different (all) laboratories.

PFS-Kontrol H\&S set enables full-scale PPE as part of preliminary, regular and $\mathrm{RHIC}$-related ME, with the output being a medical report on the FS of CNS delivered without any delay.

Prognoz H\&S set enables PPE as part of pre-shift control. The psychophysiological methods used by this H\&S set are designed to assess visual and auditory sensory systems, as well as optical-motor reactions. The results of application of each method translate into a systemic function organization stability indicator (SFOSI), which describes CNS as a single functional system.

Prognoz H\&S set employs an innovative admission control method, which allows determining whether an NF operator may be admitted to work. The method relies on the indicators reflecting normal state of each operator (personalized 


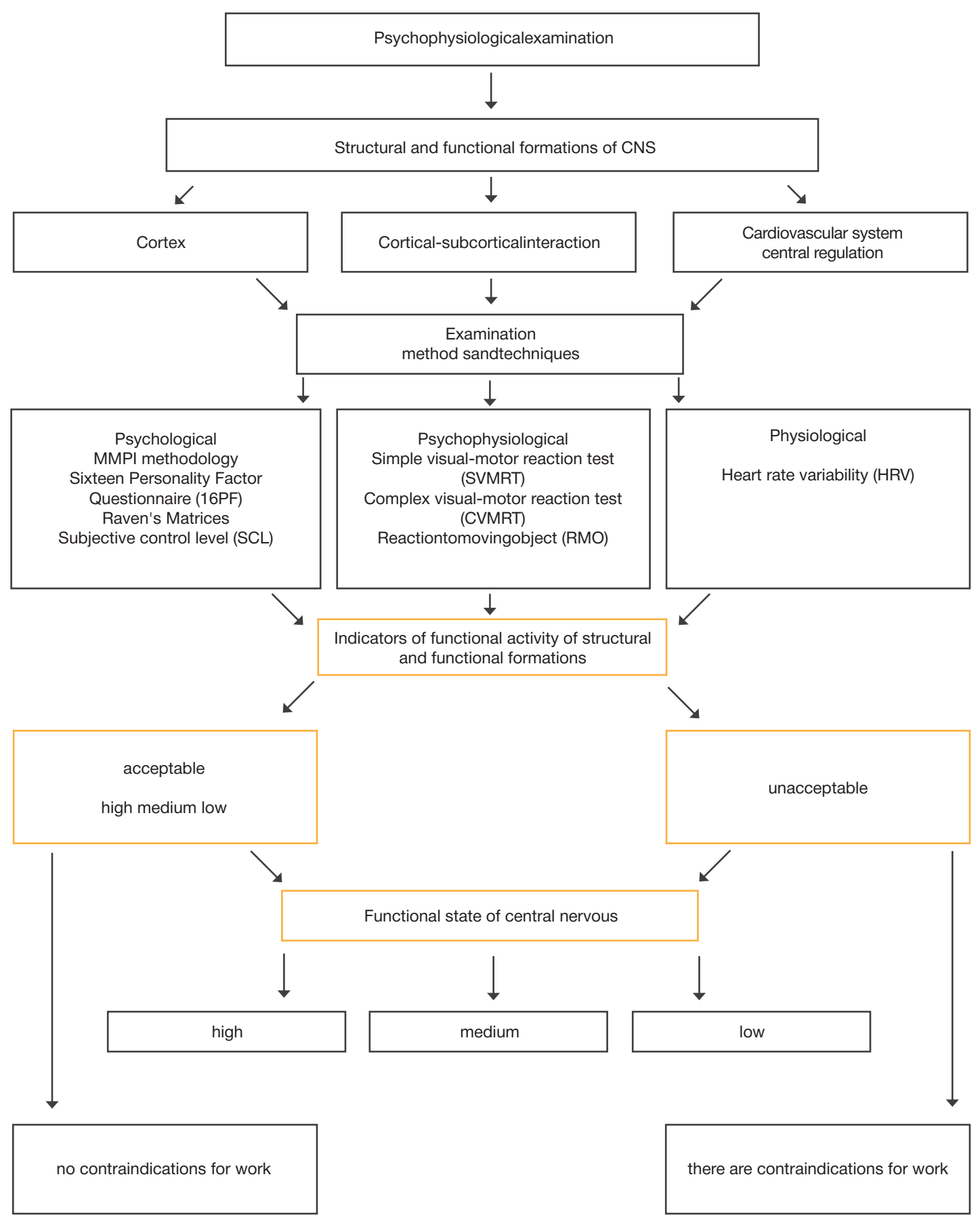

Fig. 1. Concept of psychophysiological examination

approach), the values of which accumulate and are shaped into "norms" for the given operator automatically after $20^{\text {th }}$ pre-shift checkup, provided the operator had no health complaints and was always admitted to work during the corresponding period. Personal norms factor in psychophysiological characteristics and their daily fluctuations. As the personal norm data are accumulated, it is automatically recalculated every month.

\section{Examination of Group 1: assessment of the results of PPE as part of regular ME}

Tables 1 and 2 show the results of PPE performed in the context of regular ME of 720 NPP employees. The examination made use of PFS-Kontrol H\&S set.

The FS of CNS in the majority of examined individuals was medium (56.4\%) and high (28.5\%); only $15.3 \%$ had it at the low level. The differences between groups were significant: $\chi^{2}$, $p<0.05$.

To determine the contribution of each SFF into fluctuations of FS of CNS, we analyzed the SFF indicators peculiar to high, medium and low functional activity (Table 2).

The dominating $(50.6 \%)$ SFF in cases of high FA was "Cortex". The number of "Cortical-subcortical interaction" SFF was significantly less (24.8\%), and that of "Cardiovascular system central regulation" even less $(10.3 \%)\left(\chi^{2}, p<0.05\right)$.

In cases of medium FA, the dominating SFF indicators were "Cortical-subcortical interaction" and "Cardiovascular system central regulation" (61.9\% and 59.9\%, respectively). The "Cortex" SFF was slightly less (47.7\%), however, the differences with the number of "Cortical-subcortical interaction" and "Cardiovascular system central regulation" SFF were significant $\left(\chi^{2}, p<0.05\right)$. 


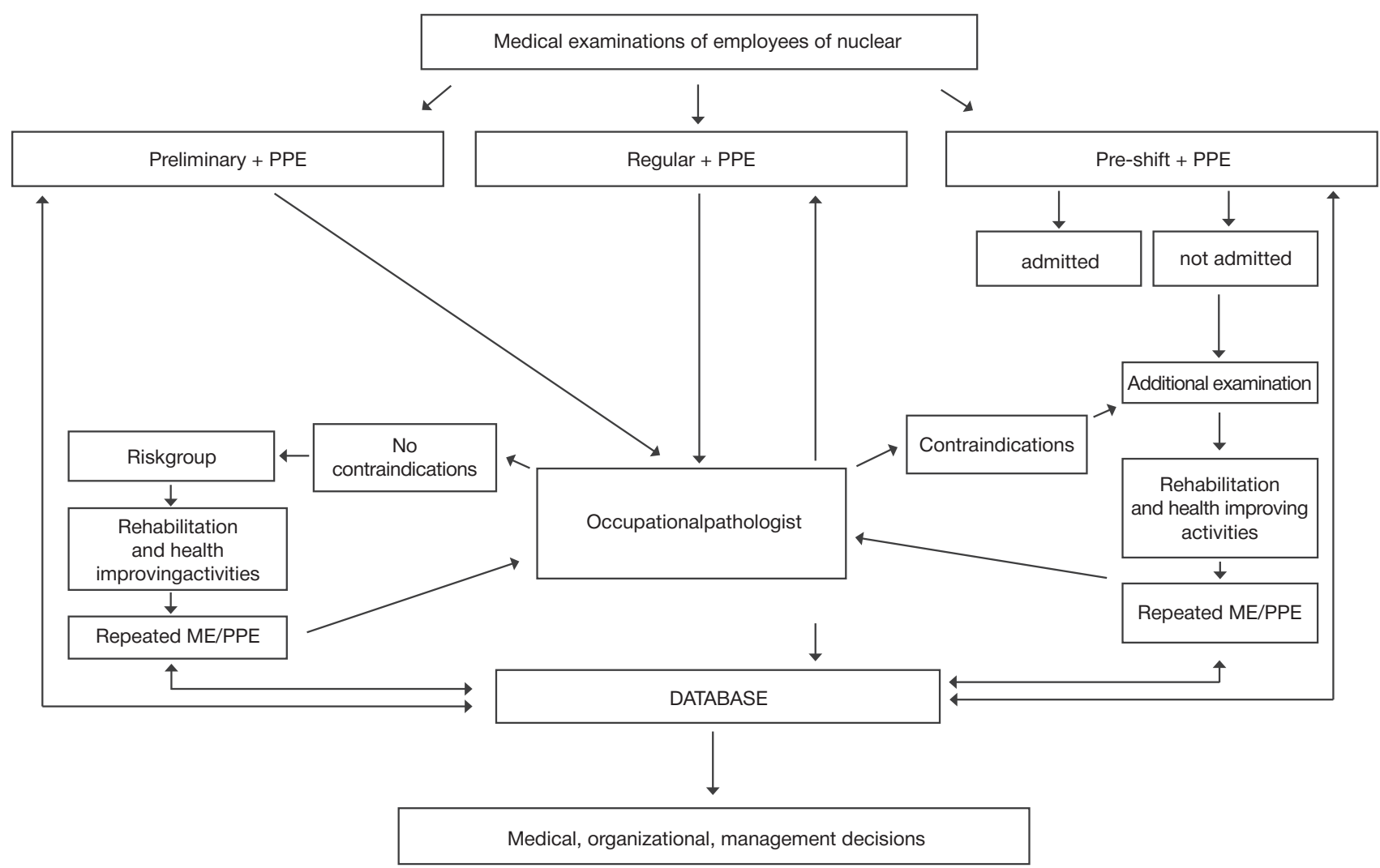

Fig. 2. Medical monitoring system for employees of nuclear facilities

At high FA, the dominating indicators were those of "Cardiovascular system central regulation" (relative to the indicators of the "Cortical-subcortical interaction" and "Cortex" SFF) $-29.9 \%$ versus $12.3 \%$ and $3.2 \%$ (the differences between the groups are significant: $\left.\chi^{2}, p<0.05\right)$.

Based on the data presented, it can be assumed that when SFF function at a high level, the SFF influencing FS of CNS most is the "Cortex" SFF. When the FA is medium, the most influential as the "Cortical-subcortical interaction" and "Cardiovascular system central regulation" SFF. In cases of low FA, the FA of CNS is mostly shaped by the "Cardiovascular system central regulation" SFF.

\section{Examination of Group 2: assessment of the results of pre-shift examinations}

At Kursk NPP, Prognoz-enabled PPE has been part of the preshift checkup since 2010. Every year, 260-400 people undergo such examinations. Overall, Prognoz H\&S set is used in over 70,000 pre-shift examinations a year. Every day, one or two persons are not admitted to work because of the low FS of CNS. Within a year, the figure is 80 . After examination by a paramedic, $75-80 \%$ of them receive a conditional admission to the shift with notification of the shift manager. About 15\% are not admitted and sent to the workshop therapist for additional examination.

Table 1. FS of CNS registered in Group $1(n=720)$
The results of PPE are the basis for the report (Table 3) that contains all the indicators and admission data.

As the report above shows, operator 2 had the current SFOSI value significantly exceeding his personal norm, which was the reason for him not being allowed to work.

\section{Examination of Group 3: PPE before and after RHIC}

The pre- and post-RHIC PPE was carried out in the psychophysiological laboratory of the Center for Occupational Pathology of the State Scientific Center of A. I. Burnazyan Federal Medical and Biological Center.

Before $\mathrm{RHIC}$, all patients had the mean time of sensorimotor reactions slightly increased, although within the permissible value range. The integral indicator of visual-motor reaction tests (SVMRT, CVMRT) determined by the mean time of sensorimotor reactions and the number of precise reactions, was below normal in all of them (Table 4).

$\mathrm{RHIC}$ improved the visual-motor test indicators significantly, which confirms improvement of the FS of CNS.

\section{DISCUSSION}

The presented concept of psychophysiological examination of NF personnel corresponds to the existing concepts of adaptation, the basis for which is the theory of functional

\begin{tabular}{|c|c|c|}
\hline \multirow{2}{*}{ FS of CNS } & \multicolumn{2}{|c|}{ Examinedindividuals } \\
\cline { 2 - 3 } & abs. & 28.5 \\
\hline High & 205 & $56.4^{*}$ \\
\hline Medium & 406 & $15.3^{*}$ \\
\hline Low & 110 & \multicolumn{2}{|c|}{} \\
\hline
\end{tabular}

Note: * - significant differences with the group showing high indicator value at $(p<0.5)$, as established by the $\chi^{2}$ test 
Table 2. SFF CNS indicators at high, medium and low functional activity, Group $1(n=720)$

\begin{tabular}{|c|c|c|c|c|c|c|}
\hline \multirow{3}{*}{ SFF CNS } & \multicolumn{6}{|c|}{ Functionalactivity } \\
\hline & \multicolumn{2}{|c|}{ High } & \multicolumn{2}{|c|}{ Medium } & \multicolumn{2}{|c|}{ Low } \\
\hline & abs. & $\%$ & abs. & $\%$ & abs. & $\%$ \\
\hline "Cortex" & 365 & 50,6 & 340 & 47,2 & 15 & 3,2 \\
\hline "Cortical-subcorticalinteraction" & 179 & $24,8^{*}$ & 446 & $61,9^{*}$ & 95 & $13,2^{*}$ \\
\hline "Cardiovascularsystemcentralregulation" & 74 & $10,3^{* *}$ & $431^{*}$ & $59,9^{*}$ & 215 & $29,9^{* *}$ \\
\hline
\end{tabular}

Note: * - significant differences with SFF "Cortex" at $(p<0.5)$, as shown by the $\chi^{2}$ test; * - significant differences with SFF "Cortical-subcortical interaction" at $(p<0.5)$, according to the $\chi^{2}$ test

Table 3. Automated PPE reportexample

\begin{tabular}{|c|c|c|c|c|c|c|c|c|}
\hline \multirow{2}{*}{\multicolumn{2}{|c|}{ \# Name }} & \multirow{3}{*}{ Shop } & \multirow{3}{*}{ Position } & \multicolumn{4}{|c|}{ SFOSI indicators } & \multirow{3}{*}{$\begin{array}{l}\text { Admitted/ } \\
\text { Notadmitted } \\
\text { Admission }\end{array}$} \\
\hline & & & & \multirow{2}{*}{$\begin{array}{l}\text { Mean } \\
1145\end{array}$} & \multirow{2}{*}{$\frac{\operatorname{RMS}(\sigma)}{682}$} & \multirow{2}{*}{$\begin{array}{l}\text { Personal admission threshold } \\
(\text { mean }+2 \sigma) \\
2505\end{array}$} & \multirow{2}{*}{$\begin{array}{c}\begin{array}{c}\text { Current SFOSI } \\
\text { value }\end{array} \\
1953\end{array}$} & \\
\hline 1 & 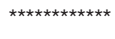 & & & & & & & \\
\hline 2 & 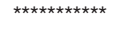 & «---------« & «---------« & 3241 & 1498 & 6237 & 7320 & Non-admission \\
\hline
\end{tabular}

Table 4. Integral indicator of visual-motor reaction tests, RHIC patients $(n=24)$

\begin{tabular}{|c|c|c|c|c|c|}
\hline \multicolumn{6}{|c|}{ Integral indicator of visual-motor reaction tests. Indicator values in \% } \\
\hline \multicolumn{2}{|c|}{ Before RHIC } & \multicolumn{4}{|c|}{ After RHIC } \\
\hline \multicolumn{2}{|c|}{ Abovenorm } & \multicolumn{2}{|c|}{ Norm } & \multicolumn{2}{|c|}{ Without changes } \\
\hline abs. & $\%$ & abs. & $\%$ & abs. & $\%$ \\
\hline 24 & 100 & 21 & 87,5 & 3 & 12,5 \\
\hline
\end{tabular}

systems [3]. These concepts state that adaptation, through structural and functional changes, leads to development of a system functioning to support the body's activities.

Adaptation is a multilevel process. The levels of adaptation are interrelated, have a direct impact on each other and determine the integral characteristic of the general level of functioning of all systems of the body, or the functional state of a person [1].

The functional state of a person is considered as a process reflecting the interaction of levels of adaptation. This is the integral indicator of psychophysiological adaptation. The existing concepts have the level of psychophysiological adaptation determined by the structural and functional formations of CNS, which, combined, shape its FS [1, 2]. Determination of the FS of CNS and the functional activity of its structural and functional formations is an important objective pursued by PPE of NF personnel.

Psychophysiological examination based on the presented concept allows determining FS of CNS, level of psychophysiological adaptation, assess the state of individual structural and functional formations of CNS ("Cortex", "Cortical-subcortical interaction", "Cardiovascular system central regulation"). Considered cumulatively, this information allows prescribing, if necessary, targeted and personalized rehabilitation and health-improving courses, and evaluate the results thereof afterwards. Data on the "Cortical-subcortical interaction" SFF enables PPE during pre-shift checkup and allows quick and accurate evaluation of the FS of CNS of the examined persons.

\section{CONCLUSION}

Introduction of a common methodological approach to PPE and a unified H\&S set to the NF employee medical care system significantly expands its diagnostic and preventive capabilities, enabling early detection of functional disorders of CNS, psychophysiological contraindications for work, timely interventions with $\mathrm{RHIC}$ and objective assessment of the results thereof. This helps to reduce the risk of human error accidents and extends professional longevity of NF personnel.

\section{References}

1. Berezin FB. Psihicheskaja i psihofiziologicheskaja adaptacija cheloveka. L.: Nauka, 1988; 270 s. Russian.

2. Krivoshhekov SG, Leutin VP, Divert VYe, Divert GM, Platonov YaG, Kovtun LT, i dr. Sistemnye mehanizmy adaptacii i kompensacii. Sibirskij nauchnyj medicinskij zhurnal. 2004; 24 (2): 148-153. Russian.

3. Sudakov KV. Obshhaja teorija funkcional'nyh sistem. M.: Medicina, 1984; 224 s. Russian.

4. Prikaz Ministerstva zdravoohranenija Rossijskoj Federacii. Metodicheskie ukazanija po provedeniju medicinskih osmotrov i psihofiziologicheskih obsledovanij rabotnikov ob"ektov ispol'zovanija atomnoj jenergii \# 32-023/20. M., 1998; $12 \mathrm{~s}$. Available from: http://docs.cntd.ru/document/9043075. Russian.

5. R FMBA Rossii 2.2.9.84-2015. Organizacija i provedenie psihofiziologicheskih obsledovanij rabotnikov organizacij, jekspluatirujushhih osobo radiacionno opasnye i jaderno opasnye proizvodstva i ob"ekty v oblasti ispol'zovanija atomnoj jenergii, pri prohozhdenii rabotnikami medicinskih osmotrov $\vee$ medicinskih organizacijah FMBA Rossii. Metodicheskie rekomendacii. M., 2015. Available from: https://sudact.ru/law/r-fmba-rossii-229842015-organizatsiia-i-provedenie/. Russian.

6. Bobrov AF, Ivanov W, Kalinina MYu, Novikova TM, Rataeva W, Sedin VI, i dr. Innovacionnaja tehnologija predsmennogo psihofiziologicheskogo obsledovanija personala kak sredstvo povyshenija radiacionnoj bezopasnosti. Medicinskaja radiologija i radiacionnaja bezopasnost'. 2018; 5: 5-10. Russian. 
7. Carjov AN, avtor, patentoobladatel'. Sposob ocenki urovnja funkcional'nogo sostojanija central'noj nervnoj sistemy cheloveka na osnove izmerenija vremeni orientirovochnoj zritel'no-motornoj reakcii cheloveka. Patent RF nomer: RU 2573340. 2016 g Russian.

8. Torubarov FS, Zvereva ZF, Lukjanova SN, Denisova EA. Rol' psihofiziologicheskogo obsledovanija $\vee$ sisteme medicinskogo monitoringa sostojanija zdorov'ja rabotnikov radiacionno jaderno opasnyh predprijatij i proizvodstv goskorporacii Rosatom.

\section{Литература}

1. Березин Ф. Б. Психическая и психофизиологическая адаптация человека. Л.: Наука, 1988; 270 с.

2. Кривощеков С. Г., Леутин В. П., Диверт В. Э., Диверт Г. М., Платонов Я. Г., Ковтун Л. Т. и др. Системные механизмы адаптации и компенсации. Сибирский научный медицинский журнал. 2004; 24 (2): 148-153.

3. Судаков К. В. Общая теория функциональных систем. М.: Медицина, 1984; 224 с.

4. Приказ Министерства здравоохранения Российской Федерации. Методические указания по проведению медицинских осмотров и психофизиологических обследований работников объектов использования атомной энергии № 32 023/20. М., 1998; 12 с. Доступно по ссылке: http://docs.cntd. ru/document/9043075.

5. РФМБА России 2.2.9.84-2015. Организация и проведение психосизиологических обследований работников организаций, эксплуатирующих особо радиационно опасные и ядерно опасные производства и объекты в области использования атомной энергии, при прохождении работниками медицинских осмотров в медицинских организациях ФМБА России. Методические рекомендации. М., 2015. Доступно по ссылке: https://sudact.ru/law/r-fmba-rossii-22984-2015-organizatsiia-iprovedenie/.

6. Бобров А. Ф., Иванов В. В., Калинина М. Ю., Новикова Т. М.,
Sovremennye problemy mediciny truda. $V$ sbornike: Materialy vserossijskoj nauchno-prakticheskoj konferencii, posvjashhennoj 80-letiju akademika RAN N. H. Amirova. Kazan', 10 aprelja 2019; 180-182. Russian.

9. Torubarov FS, Zvereva ZF, Denisova EA, Lukjanova SN. Rol' psihofiziologicheskogo obsledovanija $\vee$ ocenke funkcional'nogo sostojanija central'noj nervnoj sistemy u rabotnikov radiacionno i jaderno opasnyh predprijatij. Medicina jekstremal'nyh situacij. 2017; 2: 157-163. Russian.

Ратаева В. В., Седин В. И. и др. Инновационная технология предсменного психофизиологического обследования персонала как средство повышения радиационной безопасности. Медицинская радиология и радиационная безопасность. 2018; 5: 5-10.

7. Царёв А. Н., автор, патентообладатель. Способ оценки уровня функционального состояния центральной нервной системы человека на основе измерения времени ориентировочной зрительно-моторной реакции человека. Патент РФ номер: RU 2573340. 2016 г.

8. Торубаров Ф. С., Зверева З. Ф., Лукьянова С.Н., Денисова Е. А. Роль психофизиологического обследования в системе медицинского мониторинга состояния здоровья работников радиационно и ядерно опасных предприятий и производств госкорпорации Росатом. Современные проблемы медицины труда. В сборнике: Материалы всероссийской научнопрактической конференции, посвященной 80-летию академика РАН Н. Х. Амирова. Казань, 10 апреля 2019; 180182.

9. Торубаров Ф. С., Зверева З. Ф., Денисова Е. А., Лукьянова С. Н. Роль психосизиологического обследования в оценке функционального состояния центральной нервной системы у работников радиационно и ядерно опасных предприятий. Медицина экстремальных ситуаций. 2017; 2: 157-163. 